\title{
Ignoring detailed fast-changing dynamics of land use overestimates regional terrestrial carbon sequestration
}

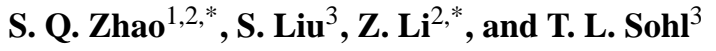 \\ ${ }^{1}$ College of Urban and Environmental Sciences, Peking University, Beijing 100871, China \\ ${ }^{2}$ Arctic Slope Regional Corporation (ASRC) Research and Technology Solutions, Contractor to US Geological Survey \\ (USGS) Earth Resources Observation and Science (EROS) Center, Sioux Falls, SD 57198, USA \\ ${ }^{3}$ USGS EROS Center, Sioux Falls, SD 57198, USA \\ *Work performed under USGS contract 08HQCN0007
}

Received: 26 February 2009 - Published in Biogeosciences Discuss.: 25 March 2009

Revised: 7 August 2009 - Accepted: 10 August 2009 - Published: 12 August 2009

\begin{abstract}
Land use change is critical in determining the distribution, magnitude and mechanisms of terrestrial carbon budgets at the local to global scales. To date, almost all regional to global carbon cycle studies are driven by a static land use map or land use change statistics with decadal time intervals. The biases in quantifying carbon exchange between the terrestrial ecosystems and the atmosphere caused by using such land use change information have not been investigated. Here, we used the General Ensemble biogeochemical Modeling System (GEMS), along with consistent and spatially explicit land use change scenarios with different intervals ( $1 \mathrm{yr}, 5 \mathrm{yrs}, 10 \mathrm{yrs}$ and static, respectively), to evaluate the impacts of land use change data frequency on estimating regional carbon sequestration in the southeastern United States. Our results indicate that ignoring the detailed fast-changing dynamics of land use can lead to a significant overestimation of carbon uptake by the terrestrial ecosystem. Regional carbon sequestration increased from 0.27 to 0.69 , 0.80 and $0.97 \mathrm{Mg} \mathrm{Cha}^{-1} \mathrm{yr}^{-1}$ when land use change data frequency shifting from 1 year to 5 years, 10 years interval and static land use information, respectively. Carbon removal by forest harvesting and prolonged cumulative impacts of historical land use change on carbon cycle accounted for the differences in carbon sequestration between static and dynamic land use change scenarios. The results suggest that it is critical to incorporate the detailed dynamics of land use change into local to global carbon cycle studies. Otherwise, it is impossible to accurately quantify the geographic distributions, magnitudes, and mechanisms of terrestrial carbon sequestration at the local to global scales.
\end{abstract}

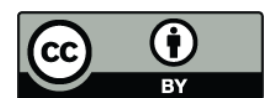

Correspondence to: S. Q. Zhao (sqzhao@urban.pku.edu.cn)

\section{Introduction}

Quantifying the carbon exchange between the terrestrial biosphere and the atmosphere due to land use change is still the biggest uncertainty in regional and global carbon cycle studies (Houghton et al., 1999; Prentice, 2001; Canadell, 2002; Achard et al., 2004; Ramankutty et al., 2007). Land use change, including land conversion from one type to another and land cover modification through land use management, has altered a large proportion of the earth's land surface (Meyer and Turner, 1992; Vitousek et al., 1997; Foley et al., 2005; Zhao et al., 2006) and disturbed the biogeochemical interactions between the terrestrial biosphere and the atmosphere (Schimel et al., 2001; Houghton and Goodale, 2004). From 1850 to 2000, roughly 35\% of global anthropogenic $\mathrm{CO}_{2}$ emissions resulted directly from land use changes (Houghton, 2003), whereas contemporary land use changes are considered to be the dominant driver for some regional terrestrial carbon sinks, contributing to a large portion of the current northern hemisphere terrestrial sink (Fang et al., 2001, 2005; Choi et al., 2002; Kauppi et al., 2006). These facts highlight the significance of including spatially explicit land use change information into the estimation of regional and global carbon exchange between the land and atmosphere. However, to date, almost all regional to global carbon cycle studies have been driven by a static land use map or land use change statistics with decadal time intervals (e.g., Potter et al., 1993; Houghton et al., 1999; Sitch et al., 2003; Krinner et al., 2005) and have failed to capture the influences of detailed rapid land use change. This can lead to significant bias in estimated regional carbon balance, and subsequently may lead to erroneous decisions. Consistent, high-quality, and spatially explicit land use change

Published by Copernicus Publications on behalf of the European Geosciences Union. 


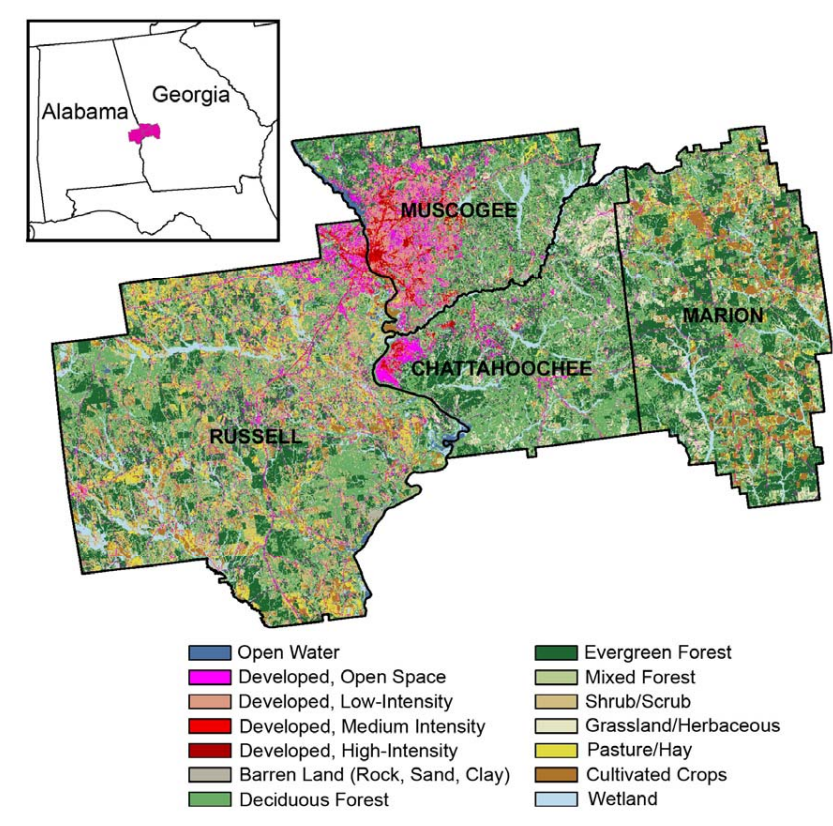

Fig. 1. The study area in Georgia and Alabama. Nearly $75 \%$ of the study area is forested, with cropland, wetland, and developed land covering most of the rest of the region. The land cover in the image is from the 2001 National Land Cover Database (Homer et al., 2007).

databases, combined with appropriate modeling techniques, may provide the best approach for accurately quantifying regional terrestrial carbon sequestration patterns. Here, we used the General Ensemble biogeochemical Modeling System (GEMS), which is capable of dynamically assimilating land use change information into the simulation process over large areas, along with four land use change scenarios with different temporal intervals ( 1 year, 5 years, 10 years, and static), to investigate the possible biases in quantifying carbon exchange between the land and atmosphere caused by ignoring detailed fast-changing dynamics of land use.

\section{Methods}

\subsection{Study area}

The study area consists of four counties: Chattahoochee, Marion, and Muscogee counties in Georgia, and Russell in Alabama. The total area is $3852 \mathrm{~km}^{2}$ (Fig. 1). The area has a subtropical climate, with an annual mean precipitation of $1245 \mathrm{~mm}$ and annual mean temperature of $17.8^{\circ} \mathrm{C}$ between 1972 and 2007. The majority of the study area is forested, with intensive industrial forestry resulting in rapid turnover between clear-cutting and regenerating forest. The city of Columbus, Georgia, and the Fort Benning military complexes account for much of the developed land, while much of the rest of the study area is covered by agricultural land and wetland.

\subsection{Model description}

GEMS has been developed to upscale carbon stocks and fluxes from sites to regions with a spatially explicit, dynamic consideration of land use change. GEMS relies on a site-scale biogeochemical model, the Erosion-DepositionCarbon Model (EDCM) (Liu et al., 2003), to simulate carbon dynamics at the site scale. The spatial deployment of the site-scale model in GEMS is based on the spatial and temporal joint frequency distribution (JFD) of major driving variables (e.g., land cover and land use change, climate, soils, disturbances, and management). The JFD was generated by overlaying these geospatial data layers with a common grid size of 250-m by 250-m spatial resolution. Model simulation units were the unique combinations of these data layers with the finest simulation unit being one grid cell (i.e., 250-m by 250-m). The uncertainties of data layers at coarser resolutions were incorporated into GEMS simulations via a Monte Carlo approach. This approach embedded in GEMS maximally uses the finest information contained in some data layers (Land use change database in this study, for example), and other coarser resolution data layers are scaled down to the finest resolution through representation of uncertainty. A more detailed description of the model can be found in Liu et al. (2004a) and Liu (2009).

\subsection{Land use change database}

Consistent, high-quality, and spatially explicit land use change databases from 1992 to 2007 at $250 \mathrm{~m} \times 250 \mathrm{~m}$ resolution were developed using the FORE-SCE (FOREcasting SCEnarios of future land cover) model (Sohl et al., 2007). FORE-SCE projects future land use changes based on historical land cover change trends, spatial characteristics of recent land cover change, and probability-of-occurrence surfaces for each unique land cover type. FORE-SCE relies heavily on Land Cover Trends data (Loveland et al., 2002) for model parameterization. We extrapolated Land Cover Trends results from the 1992 to 2000 time period, providing ecoregion-by-ecoregion annual "prescriptions" for key variables (e.g., the rates of change for individual land cover types, likelihood of specific land cover transitions, and basic characteristics of patch size) required by FORE-SCE. Logistic regression was used to develop probability-of-occurrence surfaces for each land cover type based on biophysical and socioeconomic drivers related to land use type at a given location. Individual patches of new land cover were placed on the landscape in an iterative process until the annual scenario prescriptions had been met. Patch sizes were uniquely assigned to each new patch by approximating the historical distribution of patch sizes for each land cover type. The process continues with yearly iterations, with a history variable 
tracking age classes for forest and other classes. A more detailed description of the model can be found in Sohl and Sayler (2008).

We used four land use change scenarios (land use in 1992 was the same under all scenarios) to drive GEMS to quantify the impacts of temporal frequency of land use change information on carbon sequestration and carbon sink/source patterns:

1. 1-year scenario: annual land use change data available from 1992 to 2007, which can be assumed as a real situation

2. 5-year scenario: land use change data available every five years (i.e., 1992, 1997, 2002, and 2007)

3. 10-year scenario: land use change data available every 10 years (i.e., 1992 and 2002)

4. Static scenario: 1992 land use information continued through the period of 1992 and 2007

\subsection{Other data sources}

Long-term monthly minimum temperature, monthly maximum temperature, and monthly precipitation were obtained from a 1895-2007 climate database of the United States (http://www.prism.oregonstate.edu/products/). Initial soil properties were based on the Soil Survey Geographic (SSURGO) Database (http://soils.usda.gov/survey/ geography/ssurgo/). Soil properties used included soil texture (sand, silt, and clay fractions), bulk density, organic matter content, wilting point, and field capacity. Soil drainage classes from excessively well-drained to very poorly drained were indicated by Compound Topographic Wetness Index (http://edna.usgs.gov/Edna/datalayers/cti.asp). Forest species composition, forest age, and biomass distribution data at the county level were obtained from the Forest Inventory and Analysis National Program (http://fia.fs.fed.us/ tools-data/default.asp). Initial data for the Georgia counties were inventoried in 1989, and data for the Alabama county were inventoried in 1990. Cropping practices, including shares of various crops and rotation probabilities, were derived from the National Resources Inventory (NRI) database, developed by the Natural Resources Conservation Service, US Department of Agriculture (http://www.nrcs.usda.gov/ technical/NRI/). Total atmospheric nitrogen deposition from wet and dry sources was obtained from the National Atmospheric Deposition Program (http://nadp.sws.uiuc.edu/).

\subsection{Model simulations}

We developed a data assimilation approach to inversely calculate spatially explicit model parameters from Moderate Resolution Imaging Spectroradiometer (MODIS) net primary production (NPP) (Turner at al., 2006). The averages

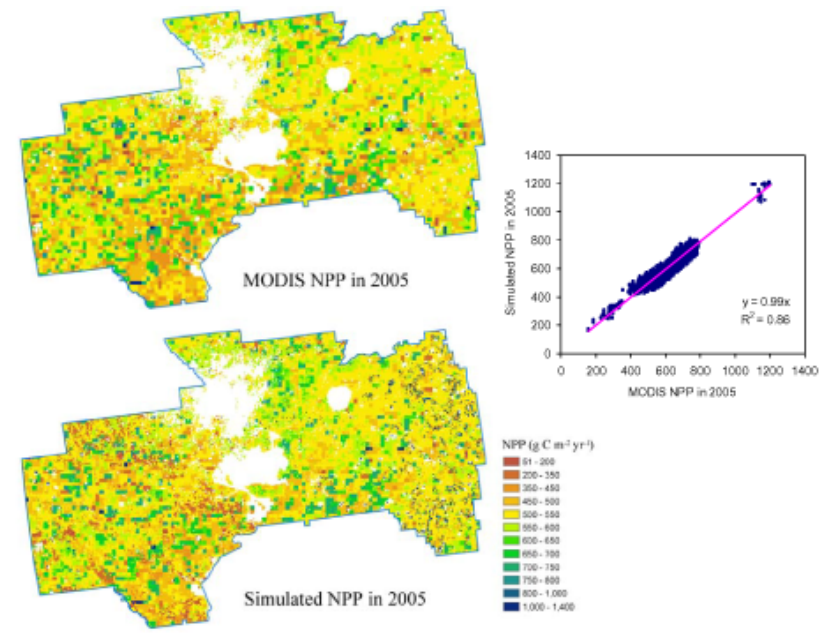

Fig. 2. Comparison of GEMS simulated (Y) and MODIS NPP (X) in $2005\left(\mathrm{Y}=0.99 \mathrm{X}, R^{2}=0.86, n=43166\right)$.

of MODIS NPP between 2000 and 2004 were used for inversion. These spatially explicit model parameters were then used to predict NPP. We used 2005 MODIS NPP for model validation. It can be seen that model simulations were in good agreement with MODIS NPP (Fig. 2). In addition, the simulated total SOC in the top 20-cm layer for Fort Benning in 2000 was $2414 \mathrm{~g} \mathrm{C} \mathrm{m}^{-2}$, which compared well with the field measurement of $2424 \mathrm{~g} \mathrm{C} \mathrm{m}^{-2}$ (Garten and Ashwood, 2004). The simulated total forest biomass carbon for counties Russell, Chattahoochee, and Marion in 2007 was 5126, 5839 , and $4236 \mathrm{~g} \mathrm{C} \mathrm{m}^{-2}$, which were in good agreement with the forest inventories of 5063, 5479, and $3968 \mathrm{~g} \mathrm{C} \mathrm{m}^{-2}$ (excluding foliage), respectively (USDA Forest Service, 2007 RPA data, available at: http://www.fia.fs.fed.us/tools-data/).

When the time interval between two consecutive land cover maps is longer than one year, there is a need to allocate the changes across all the years within the interval. Without spreading changes, artificial sudden drastic changes in simulated carbon sequestration can be generated from the model. In this study, we created a series of annual land cover maps with an interval longer than one year by allocating the total land cover changes across the years within the interval using a random uniform-distribution approach. These annual land cover maps were used to create the JFD and drive GEMS.

The land cover change maps did not include selective harvesting activities. Similar to our previous studies (e.g., Liu et al., 2004a), we derived the probability and intensity of selective cutting from Forest Inventory and Analysis (FIA) databases, and then used to stochastically schedule selective harvesting events that were not reflected in the land cover maps. It was assumed in the model that a minimum age of 20 years was required for scheduling a harvesting event in a forest. 


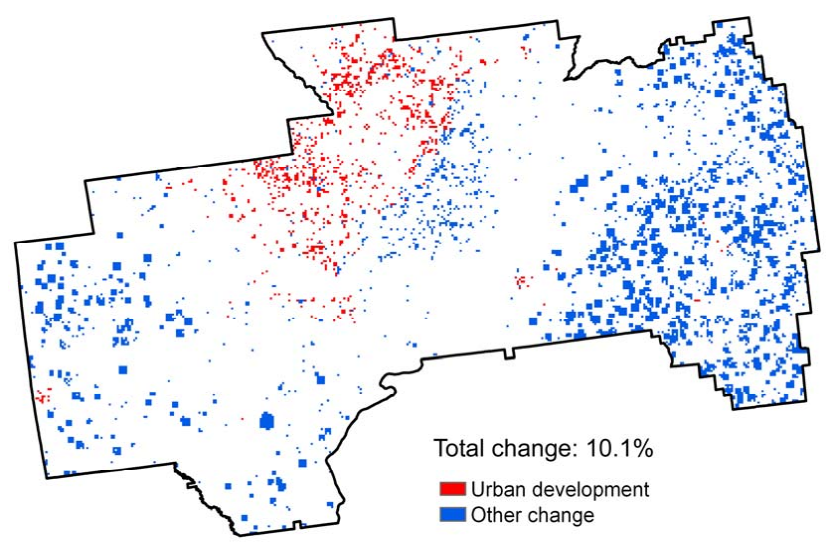

Fig. 3. 1992 to 2007 land cover change based on the 1-year frequency land use change scenario. Urban development (in red) was primarily on the outskirts of Columbus, Georgia. Other change, dominated by clear-cutting and subsequent regeneration of forest lands, primarily occurred in the eastern and western parts of the study area.

\subsection{Analysis}

Carbon sequestration was calculated by the difference between current year's and previous year's ecosystem carbon stock, which was equal to net biome productivity (NBP) using the carbon cycle concepts and terminology of Chapin et al. (2006). Positive values represent uptake, and negative values indicate carbon loss from the biome. All the fluxes (e.g., grain yield, wood harvest, and carbon sequestration) were calculated on the basis of total land area in the region.

\section{Results}

\subsection{Land use change}

Forest coverage in 1992 was $78.6 \%$, followed by cropland (7.2\%) and urban (5.7\%). The compositions of land cover categories changed gradually over time. Forest coverage decreased from $78.6 \%$ in 1992 to $76.5 \%$ in 2007 , while urban area increased from $5.7 \%$ to $7.3 \%$, suggesting that urban areas have expanded on previously forested land. The land areas under other land cover types were relatively stable. During the same period, the transitional barren category, caused primarily by forest harvesting, varied between $0.6 \%$ and $0.7 \%$ in most years, but the lowest value was in 1992 $(0.1 \%)$ and the highest value was in $2002(0.9 \%)$.

However, land use change scenarios with 5-year intervals (1992, 1997, 2002, and 2007) and 10-year intervals (1992 and 2002) or the static land use change scenario (1992 conditions continue) did not capture the detailed fast-changing dynamics of land use. $10.1 \%$ of the ecoregion changed land cover at some point between 1992 and 2007 (Fig. 3, based on the 1-year scenario). Urban development was signifi-
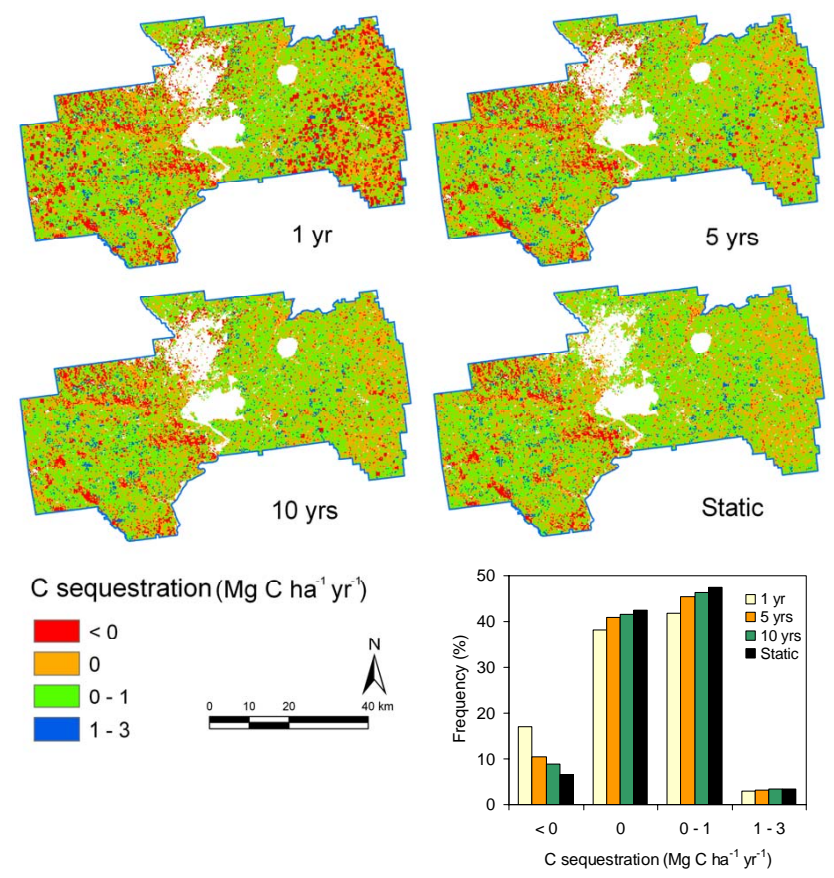

Fig. 4. The distributions of carbon sequestration for four land use scenarios between 1992 and 2007. Symbols of $1 \mathrm{yr}, 5 \mathrm{yrs}, 10 \mathrm{yrs}$, and static represent 1-year, 5-year, 10-year, and static land use scenarios, respectively. The inset graph denotes the area frequency distribution of carbon sequestration. A negative sequestration represents a movement of carbon from the biome.

cant around Columbus, Georgia, with clear-cutting and subsequent regeneration of forest dominating other parts of the study area. Clear-cutting in this area primarily consists of loblolly and other industrial pine plantations, with very rapid cutting cycles as short as 20 years. The longer the interval of land use change sequence, the more likely the detailed information will be missed, especially the rapid cyclical cutting of forest land in the eastern and western parts of the study area.

\subsection{Impacts on carbon sequestration}

The distributions of carbon sequestration between 1992 and 2007 for the four land use change scenarios showed a high degree of spatial heterogeneity (Fig. 4). Under the 1-year scenario, carbon losses (red) were mostly concentrated in the eastern and western parts, areas where land cover change is dominated by forest cutting. With the increase of the temporal interval, the spatial occurrence or extent of carbon loss decreased markedly, primarily due to the decreased ability to track rapid forest change. The areas that lost carbon in the eastern part caused primarily by forest cutting were totally missed using the static land use information. In contrast, the areal extents of carbon neutral (orange) and carbon sequestration (green and blue) for other scenarios were higher than that of the 1-year scenario. 
Overall, under the 1-year scenario, $16.9 \%$ of the region lost carbon from 1992 to 2007, 38.3\% was carbon neutral, and carbon sequestration occurred in $44.8 \%$. The magnitude of carbon sequestration was mostly in the range of 0 $1 \mathrm{Mg} \mathrm{Cha}^{-1} \mathrm{yr}^{-1}$. When using the 5-year, 10-year, and static scenarios, the area losing carbon decreased to $10.4 \%, 8.8 \%$, and $6.5 \%$, respectively. The carbon neutral area increased to $40.6 \%, 41.5 \%$, and $42.5 \%$, and the area sequestering carbon increased to $48.7 \%, 49.7 \%$, and $51.0 \%$, respectively. These results suggest that the temporal frequency of land use change information can exert a significant impact on the spatial distribution of estimated carbon sequestration over large areas. Land cover change where a given parcel transitions to a relatively static end-point, such as land developed for urban use, is likely represented well with even long temporal intervals. However, rapid cyclical change, such as the rapid cycling between clear-cuts and regenerating forest in this region, is not represented well as temporal intervals increase.

Average carbon sequestration rates from 1992 to 2007 were $0.27,0.69,0.80$, and $0.97 \mathrm{MgC} \mathrm{ha}^{-1} \mathrm{yr}^{-1}$ under 1-year, 5-year, 10-year, and static land use scenarios, respectively (Fig. 5). It was apparent that the carbon sequestration under static land use was consistently higher than sequestration under other scenarios.

Carbon sequestration demonstrated strong synchronized interannual variability for the four land use change scenarios (Fig. 5). Apparently, the synchronized variation was controlled by the interannual variability of climate. Land use change differences among these scenarios were not strong enough to change the synchronization because most land use change activities at regional scales occurred at site scale with very limited areal extent. This result suggests that smallscale land use change activities (without major land cover conversions) can only affect the magnitude, not the general pattern, of interannual variability of carbon sequestration at the regional scale.

\subsection{Impacts on regional carbon sinks}

Atmospheric carbon sources and sinks are the sum of ecosystem carbon sequestration and carbon removed by timber and grain harvesting. Crop yield was about $0.08 \mathrm{MgC} \mathrm{ha}^{-1} \mathrm{yr}^{-1}$ and was relatively stable under the various land use scenarios because change of agricultural land was minimal (Table 1). On the other hand, land use scenarios strongly affected the amount of wood removed by harvesting. Averaged harvested wood was $0.50,0.18,0.10$, and $0 \mathrm{MgCha}^{-1} \mathrm{yr}^{-1}$ during the study period under 1-year, 5-year, 10-year, and static scenarios, respectively. Combining carbon sequestration with harvested carbon, the entire region acted as a carbon sink under all land use change scenarios with a sink strength of 0.85, 0.95, 0.98, and 1.05 $\mathrm{Mg} \mathrm{Cha}^{-1} \mathrm{yr}^{-1}$ under 1-year, 5year, 10-year, and static scenarios, respectively.

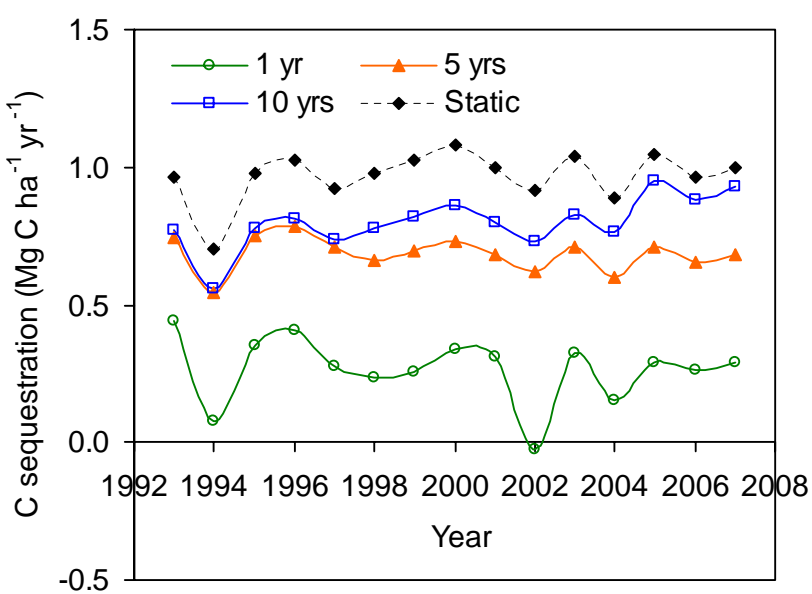

Fig. 5. Temporal changes of carbon sequestration for four land use scenarios between 1992 and 2007. Legends are the same as in Fig. 4.

\section{Discussion}

Our results indicate that ignoring the detailed fast-changing dynamics of land use can lead to a significant overestimation of carbon sequestration by the terrestrial ecosystem. Short temporal intervals in land cover mapping are necessary to capture changes such as the rapid forest cutting cycles found in this study area. However, to date, almost all regional to global carbon cycle studies are driven by a static land use map or land use change statistics with decadal time intervals, mainly due to the lack of detailed land use change databases and appropriate models capable of dynamically assimilating land use change information into the simulation processes over large areas.

This highlights two critical priorities in global carbon cycle studies. First, there is a need to develop land use change databases with appropriate temporal frequencies at regional and global scales. The Land Cover Trends project, which has adopted a cost-effective sampling strategy to study contemporary land cover and land use change in the conterminous United States (Loveland et al., 2002), provides a feasible approach for building land use change databases on a broad scale. Second, there is a need to develop methods for assimilating detailed spatially explicit data into process-based biogeochemical models over large areas. GEMS was developed for such a purpose (Liu et al., 2004a, b; Liu, 2009; Tan et al., 2005, 2006, 2007).

Timber harvesting is a dominant disturbance in the region. Our model simulated timber removal agreed well with regional estimate derived from forest inventory (Liu et al., 2004a). Selective cutting is an important forest management practice in the region, and had a significant impact on carbon sequestration. Most of the forests were aggrading young forests in the region and should be carbon sinks. However, we can see carbon sources even in the middle part of the 
Table 1. Carbon sequestration, carbon sink, and land use change impacts on carbon sequestration for four land use change scenarios from 1992 to 2007. Total impact of land use change on carbon sequestration (It), calculated as the difference in carbon sequestration rates between static and dynamic land use change scenarios. It can further be partitioned into instant impact and prolonged cumulative impact. Instant impact of land use change on carbon sequestration (Ii), calculated as the difference in the amount of carbon removed through timber and grain harvesting between static and dynamic land use change scenarios. The prolonged cumulative impact of antecedent land use change activities on the subsequent carbon biogeochemical cycle (Ip), calculated as the difference between total land use change impact and instant impact (i.e., Ip=It-Ii). Units for all carbon fluxes are $\mathrm{MgC} \mathrm{ha}^{-1} \mathrm{yr}^{-1}$.

\begin{tabular}{|c|c|c|c|c|c|c|c|}
\hline \multirow{2}{*}{$\begin{array}{l}\text { Land use } \\
\text { scenario }\end{array}$} & \multirow{2}{*}{$\begin{array}{l}\text { Carbon } \\
\text { Sink }\end{array}$} & \multirow{2}{*}{$\begin{array}{l}\text { Carbon } \\
\text { sequestration }\end{array}$} & \multirow{2}{*}{$\begin{array}{l}\text { Wood } \\
\text { harvesting }\end{array}$} & \multirow{2}{*}{$\begin{array}{l}\text { Crop } \\
\text { yield }\end{array}$} & \multicolumn{3}{|c|}{ Land Use Change Impact } \\
\hline & & & & & $\begin{array}{l}\text { Instant } \\
\text { (Ii) }\end{array}$ & $\begin{array}{l}\text { Prolonged } \\
\text { (Ip) }\end{array}$ & $\begin{array}{l}\text { Total } \\
\text { (It) }\end{array}$ \\
\hline 1-year & 0.85 & 0.27 & 0.50 & 0.08 & 0.50 & 0.20 & 0.70 \\
\hline 5-year & 0.95 & 0.69 & 0.18 & 0.08 & 0.18 & 0.10 & 0.28 \\
\hline 10-year & 0.98 & 0.80 & 0.10 & 0.08 & 0.10 & 0.07 & 0.17 \\
\hline Static & 1.05 & 0.97 & 0.00 & 0.08 & 0.00 & 0.00 & 0.00 \\
\hline
\end{tabular}

study areas (Fig. 4) where mapped disturbances were very minimal (Fig. 3). This was a result of selective cutting activities that were added on top of the land cover maps according to forest inventory data. The carbon sources caused by selective cutting were irrelevant to the time scales because a selective cutting event can be happen in any forest older than 20 years in the model. The combination of timescale independent selective cuttings with uneven distribution of clear-cuttings in the region made selective cutting an important factor in shaping the geographic distribution of carbon sequestration and the differences between time scales. Apparently, there is an urgent need for mapping selective cutting activities using remote sensing techniques to improve the quantification of changes in carbon stocks and fluxes at various scales.

From the land cover map (Fig. 1), we can see that land use in the west (i.e., Russell County in Alabama) had more lands in pasture/hay, grasslands, and shrub/scrub than in the eastern part of the region (i.e., three counties in Georgia). Although forest was the dominant land cover in the eastern part, active and widespread forest cutting only happened in Marion County (see Figs. 1 and 3) while land use change in other two counties was relatively small (except urbanization). This east-to-west difference in land use practices across political boundaries resulted in obvious differences in carbon dynamics. First, land use pattern has a significant impact on the spatial pattern of carbon sequestration. In the western part, grassland and shrub/scrub lands were usually carbon sources from 1992 to 2007 (shown in red in Fig. 4). This general source pattern was rather consistent across different intervals and not affected by the length of time interval between land cover maps. This is because these sources were associated with specific land covers, in this case grasslands and shrub/scrub lands, and not with land cover changes or transitions. Second, the change of spatial pattern of carbon sequestration in the eastern part (especially in Marion
County, Fig. 4) was caused by fast land use change activities (i.e., forest cutting under short rotation forestry) and temporal interval of the land cover maps. It was apparent that carbon source strength was under-estimated when land cover change map interval was longer than one year, implying that the recovery of spectral signals of land cover took less than five years in the region. Third, the carbon sequestration pattern under the static land cover scenario probably reflected the long-term impacts of land cover change (i.e., longer than 15 years with disturbances occurred before 1992). For example, the carbon sources associated with grasslands and shrub/scrub lands in the western part might be converted or abandoned from forestry or agriculture, and they were generally sustained by low ecosystem production (Fig. 1) and continuing decomposition of SOC which cannot be offset by low production. If the model keeps running forward under static scenario, the region should become carbon neutral as the ecosystems reach their equilibriums. The difference in carbon sequestration between static and other time intervals reflects short-term impacts of land use change that occurred between 1992 and 2007. This signifies the pivotal importance of temporal frequency in land use change data and its dramatic impact on the estimation of regional carbon sequestration rates. The result clearly demonstrated that the temporal interval of land use change mapping should be frequent in areas such as this where rapid cyclical land use changes are prevalent.

Land use change significantly affects the exchange of carbon between terrestrial ecosystems and the atmosphere (IPCC, 2000). However, few measures have been proposed to quantify the impact. We define three metrics to quantify the impact of land use change on estimating carbon sequestration:

1. Total impact of land use change on carbon sequestration (It), calculated as the difference in carbon sequestration 
rates between static and dynamic land use change scenarios. It can further be partitioned into instant impact and prolonged cumulative impact.

2. Instant impact of land use change on carbon sequestration (Ii), calculated as the difference in the amount of carbon removed through timber and grain harvesting between static and dynamic land use change scenarios.

3. The prolonged cumulative impact of antecedent land use change activities on the subsequent carbon biogeochemical cycle (Ip), calculated as the difference between total land use change impact and instant impact (i.e., $\mathrm{Ip}=\mathrm{It}-\mathrm{Ii}$ ).

The instant, prolonged, cumulative, and total impacts of land use change under various land use change scenarios are shown in Table 1. The results demonstrate that the total impact of land use change on carbon sequestration decreased with the decrease of temporal frequency of land use change data. Although both the instant and prolonged impacts of land use change decreased accordingly, the instant impact decreased faster than the prolonged cumulative impact. Consequently, the weight of prolonged impact in the total impact of land use change increased from $29 \%$ to $41 \%$ when land use scenarios changed from 1-year to 10-year.

Our results also demonstrate that ignoring the detailed fast-changing dynamics of land use had a lesser impact on estimating atmospheric carbon sources and sinks than on estimating regional carbon sequestration (i.e., NBP). This is because carbon sequestration is affected by both land use activities such as harvesting and the long-term cumulative impacts of land use change, while atmospheric carbon sources and sinks are only affected by the cumulative impact of land use change. However, we should recognize that most of the land use change activities in the region were timber harvesting, not dramatic conversions among land use categories. The partitioning of total impact into instant and prolonged cumulative impacts might differ from this study if dramatic land use change occurs, and the impact of land use change on regional carbon sources and sinks might increase.

The evolution of the terrestrial carbon sequestration and carbon sources and sinks strongly depends on the changes in land use over time (Schimel et al., 2001). Therefore, it is critical to map land use change dynamics at an adequate temporal frequency and incorporate detailed land use change dynamics into carbon cycle studies over large areas. Otherwise, it is impossible to accurately quantify the geographic distributions, magnitudes, and mechanisms of the terrestrial carbon sequestration and carbon sources and sinks at local to global scales.

Acknowledgements. This study is supported by the Department of Defense's Strategic Environmental Research and Development Program (SERDP) (project SI-1642), and US Geological Survey's Geographic Analysis and Monitoring (GAM) and the Earth Surface
Dynamics (ESD) Programs. We thank S. Poppenga and B. Worstell for their help on getting the CTWI data. S. Q. Zhao acknowledges the support of the Outstanding Young Fellow Program of Peking University.

Edited by: J. Leifeld

\section{References}

Achard, F., Eva, H. D., Mayaux, P., Stibig, H. J., and Belward, A.: Improved estimates of net carbon emissions from land cover change in the tropics for the 1990s, Global Biogeochem. Cy., 18, GB2008, doi:10.1029/2003GB002142, 2004.

Canadell, J. G.: Land use effects on terrestrial carbon sources and sinks, Science in China Series C-Life Sciences, 45, 1-9, 2002.

Chapin, F. S., Woodwell, G. M., Randerson, J. T., Rastetter, E. B., Lovett, G. M., Baldocchi, D. D., Clark, D. A., Harmon, M. E., Schimel, D. S., Valentini, R., Wirth, C., Aber, J. D., Cole, J. J., Goulden, M. L., Harden, J. W., Heimann, M., Howarth, R. W., Matson, P. A., Mcguire, A. D., Melillo, J. M., Mooney, H. A., Neff, J. C., Houghton, R. A., Pace, M. L., Ryan, M. G., Running, S. W., Sala, O. E., Schlesinger, W. H., and Schulze, E. D.: Reconciling carbon-cycle concepts, terminology, and methods, Ecosystems, 9, 1041-1050, 2006.

Choi, S. D., Lee, K., and Chang, Y. S.: Large rate of uptake of atmospheric carbon dioxide by planted forest biomass in Korea, Global Biogeochem. Cy., 16, 1089, doi:10.1029/2002GB001914, 2002.

Fang, J. Y., Chen, A. P., Peng, C. H., Zhao, S. Q., and Ci, L.: Changes in forest biomass carbon storage in China between 1949 and 1998, Science, 292, 2320-2322, 2001.

Fang, J. Y., Oikawa, T., Kato, T., Mo, W. H., and Wang, Z. H.: Biomass carbon accumulation by Japan's forests from 1947 to 1995, Global Biogeochem. Cy., 19, GB2004, doi:10.1029/2004GB002253, 2005.

Foley, J. A., Defries, R., Asner, G. P., Barford, C., Bonan, G., Carpenter, S. R., Chapin, F. S., Coe, M. T., Daily, G. C., Gibbs, H. K., Helkowski, J. H., Holloway, T., Howard, E. A., Kucharik, C. J., Monfreda, C., Patz, J. A., Prentice, I. C., Ramankutty, N., and Snyder, P. K.: Global consequences of land use, Science, 309, 570-574, 2005.

Garten, C. T. and Ashwood, T. L.: Land Cover Differences in Soil Carbon and Nitrogen at Fort Benning, Georgia. ORNL/TM2004/14, Oak Ridge National Laboratory, Oak Ridge, TN 37831, 2004.

Homer, C., Dewitz, J., Fry, J., Coan, M., Hossain, N., Larson, C., Herold, N., McKerrow, A., VanDriel, J. N., and Wickham, J.: Completion of the 2001 National Land Cover Database for the Conterminous United States, Photogrammetric Engineering and Remote Sensing, 73, 337-341, 2007.

Houghton, R. A., Hackler, J. L., and Lawrence, K. T.: The US carbon budget: contributions from land-use change, Science, 285 , 574-578, 1999.

Houghton, R. A.: Revised estimates of the annual net flux of carbon to the atmosphere from changes in land use and land management 1850-2000, Tellus B, 55, 378-390, 2003.

Houghton, R. A. and Goodale, C. L.: Effects of land-use change on the carbon balance of terrestrial ecosystems, in Ecosystems and land use change, edited by: DeFries, R. S., Asner, G. P., 
and Houghton, R. A., American Geophysical Union, Washington, DC, 85-98, 2004.

Kauppi, P. E., Ausubel, J. H., Fang, J. Y., Mather, A. S., Sedjo, R. A., and Waggoner, P. E.: Returning forests analyzed with the forest identity, Proceedings of the National Academy of Sciences of the United States of America, 103, 17574-17579, 2006.

Krinner, G., Viovy, N., de Noblet-Ducoudre, N., Ogee, J., Polcher, J., Friedlingstein, P., Ciais, P., Sitch, S., and Prentice, I. C.: A dynamic global vegetation model for studies of the coupled atmosphere-biosphere system, Global Biogeochem. Cy., 19, GB1015, doi:10.1029/2003GB002199, 2005.

IPCC.: Land use, Land-use change, and forestry, A special report of the Intergovernmental Panel of Climate Change, edited by: Watson, R. T., Noble, I. R., and Bolin, B., Cambridge University, Cambridge, UK, 2000.

Liu, S.: Quantifying the spatial details of carbon sequestration potential and performance, in Science and Technology of Carbon Sequestration, edited by B. McPherson and E. Sundquist, American Geophysical Union, in press, 2009.

Liu, S., Bliss, N., Sundquist, E., and Huntington, T. G.: Modeling carbon dynamics in vegetation and soil under the impact of soil erosion and deposition, Global Biogeochem. Cy., 17, 1074, doi:10.1029/2002GB002010, 2003.

Liu, S., Loveland, T. R., and Kurtz, R. M.: Contemporary carbon dynamics in terrestrial ecosystems in the Southeastern plains of the United States, Environmental Management, 33, S442-S456, 2004a.

Liu S., Kaire, M., Wood, E., Diallo, O., and Tieszen, L. L.: Impacts of land use and climate change on carbon dynamics in south-central Senegal, Journal of Arid Environments, 59, 583604, 2004b.

Loveland, T. R., Sohl, T. L., Stehman, S. V., Gallant, A. L., Sayler, K. L., and Napton, D. E.: A strategy for estimating the rates of recent United States land-cover changes, Photogrammetric Engineering and Remote Sensing, 68, 1091-1099, 2002.

Meyer, W. B. and Turner, B. L.: Human-population growth and global land-use cover Change, Annual Review of Ecology and Systematics, 23, 39-61, 1992.

Potter, C. S., Randerson, J. T., Field, C. B., Matson, P. A., Vitousek, P. M., Mooney, H. A., and Klooster, S. A.: Terrestrial ecosystem production: A process model based on global satellite and surface data, Global Biogeochem. Cy., 7, 811-842, 1993.

Prentice, I. C.: The carbon cycle and atmospheric carbon dioxide, in Climate Change 2001: The Scientific Basis, edited by: Houghton, J. T. and Ding, Y. H., 183-237, Cambridge Univ. Press, Cambridge, 2001.

Ramankutty, N., Gibbs, H. K., Achard, F., Defriess, R., Foley, J. A., and Houghton, R. A.: Challenges to estimating carbon emissions from tropical deforestation, Global Change Biol., 13, 5166, 2007.
Schimel, D. S., House, J. I., Hibbard, K. A., Bousquet, P., Ciais, P., Peylin, P., Braswell, B. H., Apps, M. J., Baker, D., Bondeau, A., Canadell, J., Churkina, G., Cramer, W., Denning, A. S. ,Field, C. B., Friedlingstein, P., Goodale, C., Heimann, M., Houghton, R. A., Melillo, J. M., Moore, B., Murdiyarso, D., Noble, I., Pacala, S. W., Prentice, I. C., Raupach, M. R., Rayner, P. J., Scholes, R. J., Steffen, W. L., and Wirth, C.: Recent patterns and mechanisms of carbon exchange by terrestrial ecosystems, Nature, 414, 169-172, 2001.

Sitch, S., Smith, B., Prentice, I. C., Arneth, A., Bondeau, A., Cramer, W., Kaplan, J. O., Levis, S., Lucht, W., Sykes, M. T., Thonicke, K., and Venevsky, S.: Evaluation of ecosystem dynamics, plant geography and terrestrial carbon cycling in the LPJ dynamic global vegetation model, Global Change Biol., 9, 161185, 2003.

Sohl, T. L., Sayler, K. L., Drummond, M. A., and Loveland, T. R.: The FORE-SCE model: A practical approach for projecting land use change using scenario-based modeling, Journal of Land Use Science, 1, 1-24, 2007.

Sohl, T. L. and Sayler, K. L.: Using the FORE-SCE model to project land cover change in the southeastern United States, Ecological Modelling, 219, 49-65, 2008.

Tan, Z., Liu, S., Johnston, C. A., Loveland, T. R.,Tieszen, L. L., Liu, J. X., and Kurtz, R.: Soil organic carbon dynamics as related to land use history in the Northwestern Great Plains, Global Biogeochem. Cy., 19, GB3011, doi:10.1029/2005GB002536, 2005.

Tan, Z., Liu, S., Johnston, C. A., Liu, J. X., and Tieszen, L. L.: Analysis of ecosystem controls on soil carbon source-sink relationships in the northwest Great Plains, Global Biogeochem. Cy., 20, GB4012, doi:10.1029/2005GB002610, 2006.

Tan, Z., Liu, S., Li, Z. P., and Loveland, T. R.: Simulated responses of soil organic carbon stock to tillage management scenarios in the Northwest Great Plains, Carbon Balance and Management, 2(7), doi:10.1186/1750-0680-2-7, 2007.

Turner, D. P., Ritts, W. D., Cohen, W. B., Gower, S. T., Running, S. W., Zhao, M. S., Costa, M. H., Kirschbaum, A. A., Ham, J. M., Saleska, S. R., and Ahl, D. E.: Evaluation of MODIS NPP and GPP products across multiple biomes, Remote Sens. Environ., 102, 282-292, 2006.

Vitousek, P. M., Mooney, H. A., Lubchenco, J., and Melillo, J. M.: Human domination of earth's ecosystems, Science, 277, 494 499, 1997.

Zhao, S. Q., Peng, C. H., Jiang, H., Tian, D. L., Lei, X. D., and Zhou, X. L.: Land use change in Asia and the ecological consequences, Ecol. Res., 21, 890-896, 2006. 